Marju Luts-Sootak, Dr. iur.

Professor of Legal History, University of Tartu, Estonia

Hesi Siimets-Gross, Dr. iur.

Associate Professor of Roman Law and Legal History,

University of Tartu, Estonia

\title{
BALTIC PEASANTS AFTER EMANCIPATION - FREE AND EQUAL PEOPLE OR A NEW SOCIAL ESTATE IN THE ESTATE-BASED SOCIETY?
}

\begin{abstract}
Summary
In the Baltic provinces of the Russian Empire, the majority of the population was unfree, serfs, who were part of the land owner's property. The legal acts for peasant emancipation for Estonia were enacted in 1816, whereas for Courland - in 1817, and for Livonia - in 1819. With those acts, the peasants were liberated, nonetheless, they did not become free and equal persons like, for example, in France after revolution or in Prussia from 1810, but rather found themselves in a new estate in the estate-based society. In Prussia, mobility between estates was ensured, while in the Baltic provinces, as a rule, each member of an estate had to remain there. The peasant community was, however, organised in a modern way according to the division of powers. In addition, the table of ranks offered the opportunity to change one's social estate by means of higher education.
\end{abstract}

Keywords: abolition of serfdom, personal liberation, the $19^{\text {th }}$ century, Baltic provinces of the Russian empire, peasant community

\section{Introduction}

At the beginning of the $19^{\text {th }}$ century, the peasants formed approximately $95 \%$ of the total population in the Baltic provinces of the Russian Empire. The peasants were mainly serfs: in Estonia (German Estland), only $3.5 \%$ of the peasants were free, in Livonia (German Livland) only $1.5 \%$ were free, and in Courland (German Kurland) $-9.5 \%$ were free. The Baltic provinces were territories of so-called severe serfdom: a serf was a part of the owner's property and could be sold with land or without it. He could not autonomously end his relationship with the owner. Thus, scholars and lawyers of that period, especially in Eastern Europe, sometimes compared the serfs with Roman slaves, although emphasizing that this was not their 
legal status. ${ }^{1}$ The peasants in the Baltic provinces were emancipated earlier than in the "inner" provinces of Russian territory and partially before emancipation in the former Polish territories (1861). ${ }^{2}$ The legal acts for peasant emancipation for Estonia were enacted in 1816, whereas for Courland - in 1817, and for Livonia in $1819 .^{3}$

Nowhere was peasant emancipation just a liberation of peasants from serfdom or from being tied to the land, as well as from their obligations to their landlords. As the peasants represented the majority in European societies that were just undergoing modernisation, their emancipation, together with all the manifestations thereof, must be regarded as a constitutional prerequisite for a modern society of free and equal people. ${ }^{4}$ In order to make such a society possible at all, at least three fundamental types of liberation were necessary: the liberation of the person, of property, and of work. ${ }^{5}$ This multifaceted liberation process is expressed very vividly and illustratively in the Prussian October Edict of 9 October 1807. At first, the title seems like one of the many regulations that had affected land ownership or possession in the rural territories since the early modern era: Edict Concerning the Unburdened Possession and the Free Use of Land, as well as the Personal

1 The research and writing of this article is supported by Estonian Research Council grants PUT1030 and IUT20-50.

See Knothe H.-G. Zur Entwicklung des Rechts der Gutsherrschaft im deutschen Ostseeraum im Spiegel von Mevius' Abhandlung über die "Bauers-Leute" [On the Evolution of the Legal Framework of the Concept of Gutsherrschaft in the German Baltic Sea Area as reflected in Mevius' Writings on Peasants]. In: Geschichte und Perspektiven des Rechts im Ostseeraum. Erster Rechtshistorikertag im Ostseeraum 8.-12. März 2002 [History and Perspectives of Law in the Baltic Sea Area. First Conference in Legal History in the Baltic Sea Area, $8^{\text {th }}-12^{\text {th }}$ March 2002], Eckert J., Modéer K. A.. (eds.), Frankfurt/M. et al.: Peter Lang, 2002, pp. 237-274; about the serfdom regulations in the Baltic region at the end of the $16^{\text {th }}$ century, see Hoffmann T., Siimets-Gross H. The Institute of Serfdom in the Hilchen's Land Law Draft of 1599 - a Regional Comparison. In the current volume.

2 Tarkiainen Ü. Estland and Livland as test for agricultural innovation in the Russian empire in the $19^{\text {th }}$ century. In: Russia on the Baltic: imperial strategies of power and cultural patterns of perception ( $16^{\text {th }}-20^{\text {th }}$ centuries). Wien: Böhlau, 2012, pp. 345-364; on the contemporary but failed attempt to abolish the serfdom in the Wilno Governorate: Bairašauskaite T. Consideration of the Project for the Abolition of Serfdom at the Dietine in the Wilno Governorate in 1817. In: Legal Science: Functions, Significance and Future in Legal Systems: Collected conference papers of the $7^{\text {th }}$ International Scientific Conference of the Faculty of Law of the University of Latvia. Riga: University of Latvia Press, 2019, pp. 18-24.

3 For the historiography of the agrarian reforms in the Baltic provinces, see Lust K. The Impact of the Baltic Emancipation Reforms on Peasant-Landlord Relations: A Historiographical Survey. Journal of Baltic Studies. No. 44, 2013, pp. 1-18.

4 In the frame of the same axiomatics, but concentrated on private law: Schäfer F. L. Transition from Feudal to Modern Society: The Impact of Abolition of Serfdom on German Private Law. In: Legal Science: Functions, Significance and Future in Legal Systems: Collected conference papers of the $7^{\text {th }}$ International Scientific Conference of the University of Latvia Faculty of Law. Riga: University of Latvia Press, 2019, pp. 25-34.

5 See more Rückert J. "Frei und sozial" als Rechtsprinzip ["Free and Social” as a Legal Principle]. Baden-Baden: Nomos, 2006, pp. 21-25. 
Relationships of the Tenant. ${ }^{6}$ However, Article 12 shows that it was supposed to be, in fact, a revolutionary edict: "On St. Martin's Day Eighteen Hundred and Ten (1810) all serfdom ends throughout our states. After St. Martin's Day 1810, there will be only free people [..].7

Accordingly, from St. Martin's Day 1810 every person in the Prussian territories was supposed to be free. The tone of the edict reminds us of a human rights declaration. Not surprisingly, Prussian peasant emancipation was not only caused by the fear of the superiority of the Napoleonic army, the ideology of the Enlightenment was also an important factor. First of all, it was meant to confer innate, inalienable and equal freedom upon all people. Peasants from the state manors of all Prussian countries had already been liberated. What the new general freedom was supposed to mean in reality, however, still required some explanation. Consequently, it was stated that the individual was free from now on, but also that "regardless of their status" everyone was free to conduct trade and to change from peasant into burgher and from burgher into peasant. ${ }^{8}$ All this ought to result in a free choice of occupation in that an ex-serf could "achieve prosperity" "by the measure of his strength". The permanent barriers of social mobility had been abolished and, while the estates remained, they functioned only in nomina.

In our article we will shed light on the Baltic version of the personal emancipation of peasants and the resulting legal status of peasants as a community and as individuals.

6 Edikt den erleichterten Besitz und den freien Gebrauch des Grundeigentums so wie die persönlichen Verhältnisse der Land-bewohner betreffend [Edict Concerning the Facilitated Possession and Free Use of the Real Estate as well as the Personal Circumstances of the Inhabitants of the Country-side]. Gesetzsammlung für die königlich preußischen Staaten [Collection of Laws for the Royal Prussian States] 1808-1810, pp. 170-173.

7 Cf.: "Mit dem Martini-Tage Eintausend Achthundert und Zehn (1810.) hört alle GutsUnterthänigkeit in Unsern sämmtlichen Staaten auf. Nach dem Martini-Tage 1810 giebt es nur freie Leute [..]."

8 Cf.: "Alles zu entfernen, was den Einzelnen bisher hinderte, den Wohlstand zu erlangen, den er nach dem Maaß seiner Kräfte zu erreichen fähig war [..]. \$ 2. Jeder Edelmann ist, ohne allen Nachtheil seines Standes, befugt, bürgerliche Gewerbe zu treiben; und jeder Bürger oder Bauer ist berechtigt, aus dem Bauer- in den Bürger- und aus dem Bürger- in den Bauerstand zu treten." [To eliminate everything that so far hindered the individual from attaining the prosperity he was able to achieve according to the measure of his strength. [..] $\$ 2$. Every nobleman is entitled to engage in bourgeois trades, without any harm of his estate; and every citizen or peasant is entitled to move from peasant to citizen and from citizen to peasant.] 


\section{Liberation of peasants in the Baltic provinces}

In comparison with the corresponding Prussian provision, the Estonian Peasant Ordinance of $1816^{9}$ explained the new freedom in an overly wordy and complex manner. Remarkably, the emphasis was on the legal basis, not on the content of freedom:

The Estonian peasants, to whom His Imperial Majesty, answering the requests of the nobility and according to the nobility's declaration of relinquishment of their rights, has promised the rights of a free estate for the future, shall receive these rights by and by within fourteen years. ${ }^{10}$

Substantially, the Courland Peasant Ordinance had a similar wording and was drafted on the basis of the last. ${ }^{11}$ Even though the Livonian Peasant Ordinance of 1819 was not forthright in mentioning the emancipation of peasants, and it was formulated in a most wordy manner, it still expressed the same basic ideas. ${ }^{12}$ Despite the enactment of the ordinances of 1816, 1817 and 1819, from which today the abolition of serfdom is accounted, the emancipation of peasants in Estonia was, according to the law, programmed to start only three years later, while for those in Livonia and Curonia four years later respectively, taking place over fourteen years. The finalisation of the emancipation, expressed in surnames for peasants, did not mean that they were free to leave the local community - there were several restrictions on free movement in the Peasant Ordinances and other laws.

9 On the prehistory of this ordinance in depth, partially based on unpublished sources Wistinghausen H. Freimaurer und Aufklärung im Russischen Reich: die Revaler Logen 1773-1820 [Freemasons and Enlightenment in the Russian Empire: the Reval Lodges 1773-1820], Vol. 2. Köln et al.: Böhlau, 2016, p. 797sq., in particular p. 827sq. On the ordinances of all three provinces see Deutsche Geschichte im Osten Europas: Baltische Länder [German History in Eastern Europe: Baltic Countries], Pistohlkors G. v. (ed.), Berlin: Siedler, 1994, p. 323sq.

10 Cf. Ehstländische Bauer-Verordnungen. Transitorisches Gesetz, I Kap. I. Abschnitt. $\$ 1$ [Estonian Peasant Ordinances. Transitory Statute, Chap. 1, Section 1 \& 1$]$. In: Ehstländische BauerVerordungen [Estonian Peasant Ordinances]. Reval: Johann Hermann Gressel, 1816, p. 12.

11 Kurländische Bauer-Verordnung für den transitorischen Zustand. Transitorisches Gesetz [Peasant Ordinance of Courland for the Transitory State]. In: Gesetzbuch für die Kurländischen Bauern. In Auftrag einer Allerhöchstverordneten Komission zur Einführung der Bauer-Verordnung [Code for Peasants of Courland. On Behalf of a Commission Decreed by Emperor for to Introduce the Peasant Ordinance]. Mitau: Steffenhagen und Sohn, 1819. Chapter I, Section I. \ 1: "Den Kurländischen Bauern sind durch die Gnade Sr. Kaiserlichen Majestät und durch die bereitwillige Entäusserung der Rechte des Kurländischen Adels auf die Leibeigenschaft der Bauern, die Rechte eines freyen Standes zugesichert worden. Während vierzehr Jahren sollen alle bisher leibeigen gewesenen Bauern in Kurland nach und nach zum Genuss dieser Rechte auf folgende Weise gelangen." [The peasants of the Courland were granted the rights of a free estate by the grace of Sr. Imperial Majesty and by the voluntary alienation of the rights of the Courland nobility to the serfdom of the peasants. During fourteen years all the peasants in Kurland who have been in bondage up to now shall gradually come to enjoy these rights in the following way.]

12 Liefländische Bauer-Verordnung [Livonian Peasant Ordinance]. In: Die Liefländische BauerVerordnung. Gesetz-Sammlung für das Jahr 1819. 1. Buch, 2. Abth.: Monat März [Livonian Peasant Ordinance. Collection of Laws for the Year 1819, Book 1, Part 2: March]. St.-Petersburg: Тип. коммиссии составления законов, 1820, p. 17 (Part 1, Chapter 1, Article 1). 
There is neither a trace of constitutional pathos nor the tone of human rights declarations in the Baltic ordinances. At the same time, the ideology of Enlightenment, inclusive of the human rights ideas was not entirely absent in contemporary society, as many literates or pastors had it. ${ }^{13}$ Mobility from one social estate to another is not mentioned, either. However, a new free estate was actually created, yet it did not grant any participation in state administration or matters of taxation, this remained within the power of the knighthood as corporations of nobility.

\section{Peasant communities formed as a result of emancipation and modern institutions that followed}

Among the peasantry, the institution of the peasant community was further developed for a while in the tradition that the first wave of so-called agrarian reform ${ }^{14}$ had created at the beginning of the century: the peasant community remained under supervision by the landlord and was supposed to share responsibility for public taxes and public duties solidarily. This, however, was about to change. Here we skip the evolution of peasant communities and the beginnings of peasant selfgovernment. ${ }^{15}$ The legal culmination of the development of the peasant community into modern self-government was the Peasant Community Code of 1866 valid for all three Baltic provinces in the same manner. ${ }^{16}$

This Peasant Community Act was initially conceived as provisional and was to be replaced with a new one. However, it remained in force until the fall of the Tsarist Empire and created a foundation for describing the rural communities as a preschool of political maturity and of free statehood for Estonians and Latvians. By this we mean

13 See, for example, Plath U. Politik als Erlösung. Überlegungen zu Karl Gottlob Sonntags Aufklärungstheologie [Politics as Salvation. Reflections on Karl Gottlob Sonntags Enlightenment Theology]. In: Politische Dimensionen der baltischen literarischen Kultur [Political Dimensions of Baltic Literary Culture], Lukas L., Schwidtal M., Undusk J. (eds.), Berlin: Peter Lang, 2018, pp. $123-161$.

14 In the first wave of agrarian reforms from the very beginning of 19th century the personal legal status of peasants was left the same, i.e. they remained serfs, but their relationship to the landlords were regulated according to the principles of the protection of peasants.

15 Seppel M. Pärisorjuse kaotamine ja talurahvakogukondade konstrueerimine Balti kubermangudes [The abolishment of serfdom and the construction of peasant communes in the Baltic provinces]. Acta et commentationes Archivi Historici Estoniae, No. 19(26), 2012, pp. 59-82; from a comparative perspective - Jansson T. Agraragesellschaftlicher Wandel und Landgemeindewesen [Chance of the Agricultural Society and Rural Communities]. Studia Baltica Stockholmensia, 1990, No. 5: The Baltic Countries 1900-1914, pp. 45-82.

16 Landgemeinde-Ordnung für die Ostseegouvernements: (Beilage zu einem Rescripte des Herrn General-Gouverneurs der Ostseegouvernements vom 1. April 1866 sub No. 394). [Peasant Community Code for the Baltic Sea Governorates: (Annex to the Rescript of the GouverneurGeneral of the Baltic Sea Governorates 1st of April 1866, no 394)] Reval: [Ehstländische Gouvernements-Typographie], 1866. 
not only the "clear separation between the estate and the peasant community" 17 , and the associated cessation of the guardianship (Germ Vormundschaft) of the landlords over the peasant communities, but also modern self-government itself. In 1934, Paul Sokolowski argued that the Baltic rural communities were distinctly democratic institutions:

A spirit very different from the basic attitude of the intellectual upper class but no less democratic developed in the peasant communities. The self-government right granted to them after the abolition of serfdom had a markedly democratic character and was early in increasingly sharp opposition to the landlords. Entire generations grew up in these rural democracies before the two republics of Estonia and Latvia were formed. ${ }^{18}$

The peasant communities were the very first institutions in the Baltic provinces where on the basis of Peasant Community Code of 1866, repeated in the Implementation Instruction of this Code, given by General Governor of Baltic governorates 19 February $1866^{19}$, the modern separation of powers can be found: the normative and executive bodies were clearly divided and brought into hierarchically ordered interaction. A distinction between judicial and administrative power was also first made at the level of the peasant communities. However, the community courts had only a very limited jurisdiction for small-scale disputes in private law and only for minor or petty violations in criminal law. Nevertheless, various elements educated the Baltic peasants and helped them to become members of the modern law-based society, for example, to achieve the settlement of conflict by legal and judicial means; the awareness of evidence being required both on the side of the parties to the dispute and on the side of the court bench; keeping written records and the awareness of the power of written evidence. ${ }^{20}$ This also applies to

17 It is also expressed in the Baltic German historiography, for example Pistohlkors G. Ritterschaftliche Reformpolitik zwischen Russifizierung und Revolution [Reform Politics of Kinghthood between Russification and Revolution]. Göttingen et al.: Musterschmidt, 1978, p. 96 or already Tobien A. Die Agrargesetzgebung Livlands im 19. Jahrhundert. Bd. 2: Die Vollendung der Bauernbefreiung [The Agrarian Legislation of Livonia in the $19^{\text {th }}$ Century. Vol. 2: The Completion of the Peasant Emancipation]. Riga: Löffler, 1911, p. 289sq.

18 Sokolowski P. Parlamentarismus und Demokratie in den Ostseerepubliken Estland und Lettland [Parliamentarism and Democracy in the Baltic Republics of Estonia and Latvia]. Zeitschrift für osteuropäisches Recht, Neue Folge [Journal for Eastern European Law, New Series], Vol. 1, 1934, p. 55.

19 See for example $\$ 21$. Vollzugs-Instruction zur Allerhöchst bestätigten Landgemeinde-Ordunung für die Ostseegouvernements vom 19. Februar 1866 (confirmed 29.6.1866) [Instruction of Execution of the Peasant Community Code for the Baltic Sea Governorates, $19^{\text {th }}$ February 1866 , Confirmed by the Emperor on $29^{\text {th }}$ June 1866]. - Sammlung der ergänzenden Bestimmungen zur Estländischen Bauer-Verordnung vom Jahre 1856 und anderer Gesetze, betreffend die Estländischen Bauern. Beilagen [Collection of Supplementary Provisions to the Estonian Peasant Ordinance of 1856 and Other Laws Concerning Estonian Peasants. Supplements]. Reval: [Ehstländische GouvernementsTypographie], 1877, p. 3.

20 Luts M. Gerichtsbarkeit im Dienst der Volkspädagogik: Rechtsprechung in Bauernsachen in Estland und Livland 1866-1889 [Jurisdiction in the Service of People's Education: Case law on Peasant Matters in Estonia and Livonia 1866-1889]. In: Liber Amicorum Kjell Å Modéer. Lund: Juristförlaget, 2007, pp. 433-448. 
the regular elections for the local community assembly. The peasant communities in the Baltic provinces were thus the first bodies to become familiar with the function of modern structures of institutions and the separation of powers. In contrast to Russian reform of the constitution and administration of cities (1892) or the police and judicial reform of $1888 / 89$, the Peasant Community Code of 1866 was not accompanied by russification, which was yet another reason it gained trust.

\section{Social mobility between the free estates}

But what about social mobility? In Prussia, for example, the estates themselves remained intact while mobility between them was made possible: the people could move from the peasantry to become burghers and vice versa; the nobility could also carry out bourgeois trade; all kinds of land could be sold on the free market.

In Baltic territories, farming and manor lands were excluded from free trade. The second volume of the Baltic Provincial Law Code of 1845, which deals with the laws of the estates, in its Article 876 states that the so-called knight manors could only be acquired by locally immatriculated noblemen. This restriction was abolished by the Imperial Acts of 1866 . Christian subjects of all estates were still eligible to acquire knight manors. Later even some Estonian and Latvian peasants bought former knight manors. We use the term "former" because the political rights (for example, participation on the diet of knighthood as local ruling body) and economic privileges (for example, a franchise to the village inns) tied to the manor were not transferred to the non-aristocratic or non-immatriculated new owner of the estate. As a consequence, one could not change one's social estate through the acquisition of a feudal estate.

However, the social estates in the Baltic provinces were not completely rigid. Similarly to Prussia, mobility between the social estates in the Baltic provinces also occurred, especially between the burgher class and the peasantry. It was possible to move this way by registering with the peasant community, and through the acquisition of farming land. Nevertheless, this did not happen very often and mainly applied to burghers of smaller towns. Burghers of larger towns, especially the burghers of Riga, fought vehemently for the right to acquire property in the country. However, they had manors in mind, and not farms.

It was the members of the peasantry who profited most from social mobility in a society that still remained estate-based. Of course, they could not just join the corporations of the nobility and the town burghers because they were free citizens. After the implementation of the Russian Town Ordinance and the abolition of the guild charters, the so-called Large Guilds in the Baltic towns functioned as registered associations, which should not be compared to present-day associations, to which everybody has a free access.

In the Russian Empire, however, one could find a peculiar social ladder, which made social advancement possible outside the estate acquired through birth in the form of the Table of Ranks, introduced by Peter the First. A university degree 
made one exempt from the poll tax, while a candidate degree gave access to the Table of Ranks. ${ }^{21}$ The empire was large enough to offer academic achievers from the Baltic peasantry a career that they would not have dreamt of in their own provinces. It is no wonder then that Estonian peasants participated in a rural exodus, especially to the capital St. Petersburg. As a result, more Estonians studied at the University of Petersburg than at the University of Dorpat (Jurjew, as the town was called after the russification was initiated in 1892).

\section{Conclusions}

The Baltic, as well as Russian peasant emancipation did not create the basis for a modern society of free and equal individuals. However, it did devise a new free estate within the framework of an estate-based society. Within this estate, relatively modern institutions and structures of self-government were soon created in the Baltic provinces. Although freedom of movement was not permitted with the ordinances of $1816 / 17 / 19$, this freedom did reach the Baltic peasantry in the second half of the $19^{\text {th }}$ century. A lot of Baltic peasants moved to the cities, often to the capital of the Russian Empire, St. Petersburg, and some of them took advantage of the possibility to rise socially, - an opportunity that was made possible for them through higher education and the Table of Ranks established by Russian Empire.

\section{BIBLIOGRAPHY}

\section{Literature}

1. Bairašauskaite T. Consideration of the Project for the Abolition of Serfdom at the Dietine in the Wilno Governorate in 1817. In: Legal Science: Functions, Significance and Future in Legal Systems: Collected conference papers of the $7^{\text {th }}$ International Scientific Conference of the Faculty of Law of the University of Latvia. Riga: University of Latvia Press, 2019, pp. 18-24.

2. Deutsche Geschichte im Osten Europas: Baltische Länder [German History in Eastern Europe: Baltic Countries]. Pistohlkors G. (ed.), Berlin: Siedler, 1994.

3. Hoffmann T., Siimets-Gross H. The Institute of Serfdom in the Hilchen's Land Law Draft of 1599 - a Regional Comparison. In the current volume.

4. Jansson T. Agraragesellschaftlicher Wandel und Landgemeindewesen [Chance of the Agricultural Society and Rural Communities]. Studia Baltica Stockholmensia, No. 5: The Baltic Countries 1900-1914, 1990.

5. Knothe H.-G. Zur Entwicklung des Rechts der Gutsherrschaft im deutschen Ostseeraum im Spiegel von Mevius' Abhandlung über die "Bauers-Leute" [On the Evolution of the Legal Framework of the Concept of Gutsherrschaft in the German Baltic Sea Area as reflected in Mevius' Writings on Peasants]. In: Geschichte und Perspektiven des Rechts im Ostseeraum. Erster Rechtshistorikertag im Ostseeraum 8.-12. März 2002 [History and Perspectives of Law

${ }^{21}$ See Waliszewski K. Peter the Great: His Life and Work. Repr. Forgotten Books, 2010, p. 454sq. 
in the Baltic Sea Area. First Conference in Legal History in the Baltic Sea Area, $8^{\text {th }}-12^{\text {th }}$ March 2002], Eckert J., Modéer K. Å. (eds.), Frankfurt/M. et al.: Peter Lang, 2002, pp. 237-274.

6. Lust K. The Impact of the Baltic Emancipation Reforms on Peasant-Landlord Relations: A Historiographical Survey. Journal of Baltic Studies, No. 44, 2013, pp. 1-18.

7. Luts M. Gerichtsbarkeit im Dienst der Volkspädagogik: Rechtsprechung in Bauernsachen in Estland und Livland 1866-1889 [Jurisdiction in the Service of People's Education: Case Law on Peasant Matters in Estonia and Livonia 1866-1889]. In: Liber Amicorum Kjell Å Modéer. Lund: Juristförlaget, 2007, pp. 433-448.

8. Pistohlkors G. Ritterschaftliche Reformpolitik zwischen Russifizierung und Revolution [Reform Politics of Kinghthood between Russification and Revolution]. Göttingen et al.: Musterschmidt, 1978.

9. Plath U. Politik als Erlösung. Überlegungen zu Karl Gottlob Sonntags Aufklärungstheologie [Politics as Salvation. Reflections on Karl Gottlob Sonntags Enlightenment Theology]. In: Politische Dimensionen der baltischen literarischen Kultur, Lukas L., Schwidtal M., Undusk J. (eds.), Berlin: Peter Lang, 2018, pp. 123-161.

10. Rückert J. "Frei und sozial" als Rechtsprinzip ["Free and Social” as a Legal Principle]. BadenBaden: Nomos, 2006.

11. Schäfer F. L. Transition from Feudal to Modern Society: The Impact of Abolition of Serfdom on German Private Law. In: Legal Science: Functions, Significance and Future in Legal Systems: Collected conference papers of the $7^{\text {th }}$ International Scientific Conference of the Faculty of Law of the University of Latvia. Riga: University of Latvia Press, 2019, pp. 25-34.

12. Seppel M. Pärisorjuse kaotamine ja talurahvakogukondade konstrueerimine Balti kubermangudes [The abolishment of serfdom and the construction of peasant communes in the Baltic provinces]. Acta et commentationes Archivi Historici Estoniae, No. 19(26), 2012, pp. 59-82.

13. Sokolowski P. Parlamentarismus und Demokratie in den Ostseerepubliken Estland und Lettland. [Parliamentarism and Democracy in the Baltic Republics of Estonia and Latvia]. Zeitschrift für osteuropäisches Recht, Neue Folge [Journal for Eastern European Law, New Series], 1934, Jg. 1 H. 2, pp. 55-66.

14. Tarkiainen Ü. Estland and Livland as test for agricultural innovation in the Russian empire in the $19^{\text {th }}$ century. In: Russia on the Baltic: imperial strategies of power and cultural patterns of perception $\left(16^{\text {th }}-20^{\text {th }}\right.$ centuries). Wien: Böhlau, 2012, pp. 345-364.

15. Tobien A. Die Agrargesetzgebung Livlands im 19. Jahrhundert. Bd. 2, Die Vollendung der Bauernbefreiung [The Agrarian Legislation of Livonia in the $19^{\text {th }}$ Century. Vol. 2: The Completion of the Peasant Emancipation]. Riga: Löffler, 1911.

16. Waliszewski K. Peter the Great: His Life and Work. Repr. Forgotten Books, 2010.

17. Wistinghausen H. Freimaurer und Aufklärung im Russischen Reich: die Revaler Logen 1773-1820, [Freemasons and Enlightenment in the Russian Empire: the Reval Lodges 1773-1820], Vol. 2. Köln et al.: Böhlau, 2016.

\section{Legislative acts}

18. Edikt den erleichterten Besitz und den freien Gebrauch des Grundeigentums so wie die persönlichen Verhältnisse der Land-bewohner betreffend [Edict Concerning the Facilitated Possession and Free Use of the Real Estate as well as the Personal Circumstances of 
the Inhabitants of the Country-side]. Gesetzsammlung für die königlich preußischen Staaten [Collection of Laws for the Royal Prussian States] 1808-1810.

19. Ehstländische Bauer-Verordungen [Estonian Peasant Ordinances]. Reval: Johann Hermann Gressel, 1816.

20. Gesetzbuch für die Kurländischen Bauern. In Auftrag einer Allerhöchstverordneten Komission zur Einführung der Bauer-Verordnung [Code for Peasants of Courland. On Behalf of a Commission Decreed by Emperor for to Introduce the Peasant Ordinance]. Mitau: Steffenhagen und Sohn, 1819.

21. Landgemeinde-Ordnung für die Ostseegouvernements: (Beilage zu einem Rescripte des Herrn General-Gouverneurs der Ostseegouvernements vom 1. April 1866 sub No. 394) [Peasant Community Code for the Baltic Sea Governorates: (Annex to the Rescript of the Gouverneur-General of the Baltic Sea Governorates, $1^{\text {st }}$ of April 1866, no 394)] Reval: [Ehstländische Gouvernements-Typographie], 1866.

22. Liefländische Bauer-Verordnung [Livonian Peasant Ordinance]. In: Die Liefländische Bauer-Verordnung. Gesetz-Sammlung für das Jahr 1819. 1. Buch, 2. Abth.: Monat März [Livonian Peasant Ordinance. Collection of Laws for the Year 1819, Book 1, Part 2: March]. St.-Petersburg: Тип. коммиссии составцения законов, 1820.

23. Vollzugs-Instruction zur Allerhöchst bestätigten Landgemeinde-Ordunung für die Ostseegouvernements vom 19. Februar 1866 [Instruction of Execution of the Peasant Community Code for the Baltic Sea Governorates, $19^{\text {th }}$ February 1866, Confirmed by the Emperor on 29 ${ }^{\text {th }}$ June 1866]. Sammlung der ergänzenden Bestimmungen zur Estländischen Bauer-Verordnung vom Jahre 1856 und anderer Gesetze, betreffend die Estländischen Bauern. Beilagen [Collection of Supplementary Provisions to the Estonian Peasant Ordinance of 1856 and Other Laws Concerning Estonian Peasants. Supplements]. Reval: [Ehstländische Gouvernements-Typographie], 1877. 